\title{
Outcomes of Labor in Women Undergoing Induction of Labor and Plan of Nursing Action
}

\author{
Prof. Sanaa Ali Nour; Dr. Nagat Salah Shalaby; Zienab Fathi Mohamed Abo Al \\ Wafa \\ Professor of Obstetrics and Gynecological Nursing - Faculty of Nursing - Zagazig \\ University; Lecturer of Maternal, Obstetrics and Gynecology Nursing - Faculty of \\ Nursing - Port Said University; B.Sc. Nursing - Mansoura University
}

\begin{abstract}
Background: Induction of labor refers to the iatrogenic stimulation of uterine contractions after the age of viability and before spontaneous onset of labor for accomplishing vaginal delivery. The Aim of this Study was to identify the outcomes of labor among women undergoing labor induction and plan of nursing action . Study Design: A prospective observational was used in labor ward at Maternity Department of Mansoura University Hospital and Dikirniss Hospital.: a purposive sample of 234 parturient women who received induction of labor. Data Collection Four tools were used; a structured interviewing schedule, maternal and neonatal assessment sheet, partograph, and Bishops score. Results: present study revealed that incidence of Induction of labor was $11.7 \%$. Almost three fifth of women (57.7\%) had successful induction of labor, while $42 \%$ underwent cesarean. The most common indication for Indication of labor (IOL) was; premature rupture of membrane (49.5\%) as for the BMI, over weight and obese women were more likely to underwent failed labor induction $(67.7 \%, 27.3 \%$ vs. $66.7 \%, 24.4 \%$ respectively). Eighty five points nine present of neonatal had no complications, while $6.7 \%$ of neonates had asphyxia. Apgar score at the first and fifth minutes was within the normal level. It can be concluded that, successful induction outcome was more likely with gestational age between 37 weeks to less than 40 weeks. Case selection for IOL is vital for achieving outcomes similar to spontaneous labor.Recommendation, monitoring of the woman and her fetus closely undergoing labor induction once labor is established by labor induction is imperative.
\end{abstract}

Key words: outcomes of labor, induction of labor, plan of nursing action 


\section{INTRODUCTION}

Induction of labor (IOL) is a common intervention during pregnancy in both developed and developing countries. It is indicated in medical, obstetric and fetal conditions in which prolongation of the pregnancy would jeopardize fetal or maternal well being and in which there are no contraindications to vaginal delivery and cesarean section could be still be postponed (Ade - Ojo et al., 2011).

The indications of induction of labor must be to save the life of the mother and the fetus. They include postdate, gestational hypertension, term, pre labor rupture of membranes, maternal medical conditions (e.g., Diabetes renal disease, hypertension) gestational $\geq 41+1 / 7$ weeks, pre - eclampsia, intra-uterine growth retardation. The potential risks associated with induction of labor include cesarean delivery, prolonged labor placenta insufficiency meconium, stained amniotic fluid, umbilical cord prolapse as well as intra-partum hemorrhage prolonged labor, precipitate labor, failed induction and primary postpartum hemorrhage (Norwiz et al., 2002).

The contra - indications to induction of labor include contra indications to labor or vaginal delivery. Example of this include; previous myomectomy entering the uterine cavity previous uterine rupture, fetal transverse lie, placenta previa, vasa previa, invasive cervical cancer, active genital herpes, and previous classical or inverted $\mathrm{T}$ uterine incision. Whenever possible for patients with prior uterine incision or surgery, the operative report or the opinion of the surgeon should be obtained and reviewed (Joan Cran et al., 2001)

Corine et al. (2013) study reported that predicting variables for failed labor induction are parity, history of pre term delivery, previous cesarean delivery, further more maternal high less than $165.7 \mathrm{~cm}$ weight gain in pregnancy $12 \mathrm{~kg}$ or more and maternal age 32 years old or more. The most common complication of induced labor is uterine hyper stimulation, accompanied by compromised fetal oxygenation. Rare complication includes uterine rupture and abruption placenta (ACOG, 2011).

The positive maternal and neonatal outcome of induction are regular and rhythmic uterine contraction progress in cervical dilation, good effacement of the cervix, shortening of the duration of labor and low incidence of CS. In addition, less maternal 
anxiety rapid delivery of the baby, early detection of fetal hypoxia and meconium staining as well as decreasing neonatal mortality rate (Dutta, 2010).

The primary role of the maternity nurse during cervical ripening and induction of labor is ongoing maternal and fetal assessment to support safe care. The goal of care is labor progression without excessive uterine activity or fetal compromise. The nurse providing care for the women during induction of labor must be aware of appropriate indications for the used methods of induction as well as their actions, expected results and potential risk factors. Maternal and fetal well-being should be established; cervical status should be assessed and documented in the medical records. The nurse should assess the fetal weight, presentation and maternal pelvis before induction of labor. Ongoing maternal and fetal assessment during induction of labor is very important (Simpson \& Creehan, 2014).

\section{AIM OF STUDY:}

The aim of this study was to identify the outcomes of labor in women undergoing labor induction and plan nursing action.

\section{SUBJECT AND METHODS:}

A prospective observational study design was utilized in this study.

The current study was conducted in Labor Ward at the Maternity Department of Mansoura University Hospital and Dikirnis Hospital. These hospitals were selected because the first is a teaching hospital while, the second is a Ministry of Health Hospital and the rate of induction and delivery turnover was satisfactory for the study. The total delivery rate during the current study period was 1715 .

Data collection was done through the use of the following tools:

(I): A Structured interviewing schedule this was developed by the researcher in order to collect of the following data:

Part 1: Personal characteristic such as age and body mass index.

Part 2: Medical history that may affect the woman's health such as diabetes mellitus, chronic hypertension and cardiac disease.

Part 3: Present pregnancy history which included data about parity and gestational age. 


\section{(II): Maternal assessment record}

\section{It included the findings of:}

- General examination on admission to labor room: such as height, weight to calculate body mass index and maternal vital signs. Women were grouped into the following BMI categories: $\mathrm{BMI}<25 \mathrm{~kg} / \mathrm{m} 2$ (normal weight), 25-29.9 kg/m2 (overweight), $30-34.9 \mathrm{~kg} / \mathrm{m} 2$ (obese) and BMI $\geq 35 \mathrm{~kg} / \mathrm{m} 2$ (morbidly obese).

- Abdominal examination to determine fetal heart rate and making sure that there were no signs of fetal distress. Also to assess the frequency, duration and intensity of uterine contractions.

- Local examinations: (per vaginal examination): It was done to determine the cervical dilation, effacement, position of the cervix, consistency of the cervix and station to calculate Bishop Score. The condition of the membranes and duration between the rupture of membranes and onset of delivery were all estimated and recorded.

- Ultrasonography: was done to assess the gestational age, fetal viability, Amniotic fluid index (AFI) and fetal weight.

\section{(III): Partograph}

The partograph was used for every participant in order to evaluate fetal and maternal condition and to evaluate the labor progress during the active phase of the first stage of labor.

\section{RESULTS:}

Table (1): presents the distribution of the studied women according to their baseline characteristics. Their ages ranged between 17 to 35 years with the mean of $25.2 \pm 3.9$. Most of them were obese and overweight (25.6\% and $67.1 \%$ respectively), with a mean of $28.8 \pm 5.2 \mathrm{~kg} / \mathrm{m}^{2}$, and partially an equal proportion of nullipara and primipara (35.9\% and $34.2 \%$ respectively).

Concerning women previous medical history table (2), shows that the majority of the women $(90.9 \%)$ had no medical problems. However, ten women $(2.8 \%)$ suffered from chronic hypertension, $3.8 \%$ had cardiac disease and $2.5 \%$ had history of diabetes mellitus. 
Table (3): reveals that the most common indication for the cesarean section was fetal distress (49.5\%) followed by non-engagement of the fetal head (17.1\%) and failure of labor progress $(12.1 \%)$. Few patients $(10.1 \%)$ were exposed to failure in labor induction because of the method used for induction, 6.1\% had hyper-stimulation and 5.1\% were exposed to labor dystocia.

As table (4): demonstrates women in the two groups had partially the same gestational weeks ( $\geq 42$ weeks, post-term pregnancy) as the most common indication of induction. However, more women with premature rupture of membrane (PROM) were exposed to failure in labor induction (49.5\%, vs. $45.2 \%$ respectively) and women who had PIH were more likely to end with failed labor induction $(9.1 \%$, vs. $5.9 \%$, respectively). While those who had Intrauterine fetal death (IUFD) were more likely to have successful induction of labor (4.4\% vs. 3.0\% respectively. Differences observed are not statistically significant.

As shown in table (5), women aged less than 25 years were significantly more liable for failed induction CS than a successful one (44.4\% vs.10.4\% respectively). As for the BMI, over weight and obese women were more likely to underwent failed labor induction $(67.7 \%, 27.3 \%$ vs. $66.7 \%, 24.4 \%$ respectively). Meanwhile, nulliparous women had a statistically higher rate of CS delivery (40.4\%) in comparison with multiparous women (32.3\%). Differences observed are statistically significant $\left(p=0.003^{*}\right)$.

Table (6): shows that almost two fifths $(42.2 \%)$ of women who received combined method of PGE1, ARM and syntocinon were significantly more likely to have successful labor induction than failed one (5.1\%). Also, women who received PEG + syntocinon were more likely to have successful induction of labor among Women in the Successful and Failure than failed one (8.9\% vs. 5.1\% respectively). While, nearly half $(48.5 \%)$ of women who underwent CS received PGE1 alone compared to those delivered by vaginal route (30.4\%). Differences observed are statistically significant $(p=0.295)$.

Regarding the influence of labor induction on the neonatal outcomes, table (7): shows neonatal complications were higher in the failed induction group than in the 
successful induction group (54.6\% vs. $14.1 \%$ respectively). It is evident that low Apgar score after 1minute was more common in women with failure in labor induction than successful induction ( $35.4 \%$ vs $14.8 \%$ respectively). The same table points to no differences of statistical significance between Apgar score after 5minutes and outcomes of induction of labor $(\mathrm{p}=0.845)$.

Figure (1): illustrates the incidence of induction of labor during the study period (8 months). The total number of deliveries in Mansoura University Hospital and in Dikerness Hospital were 1900 and 509 respectively. With a sample size of 190 patients underwent labor induction from $\mathrm{MUH}$ and 44 patients from $\mathrm{DH}$, the incidence of labor induction were $12.7 \%$ and $8.8 \%$ respectively. In total the incidence of labor induction in the two hospitals were $11.7 \%$.

Figure (2): It is obvious from figure 2 that almost three fifths (57.7\%) of women had successful induction of labor, while (42.3\%) underwent cesarean section as a result of failed labor induction. 
Table (1): Distribution of the Studied Women According to their demographic data $(n=234)$

\begin{tabular}{|c|c|c|}
\hline Items & $\begin{array}{c}\text { No. } \\
(n=234)\end{array}$ & $\%$ \\
\hline \multicolumn{3}{|l|}{ Age (years) } \\
\hline $17-<25$ & 101 & 43.2 \\
\hline $25-<30$ & 97 & 41.5 \\
\hline 30-35 & 36 & 15.4 \\
\hline Range & \multicolumn{2}{|c|}{$17-35$} \\
\hline Mean \pm SD & \multicolumn{2}{|c|}{$25.2 \pm 3.9$} \\
\hline \multicolumn{3}{|l|}{ General maternal examination BMI } \\
\hline \multicolumn{3}{|l|}{ Normal $(\mathrm{BMI}<25)$} \\
\hline Overweight $(30>\mathrm{BMI} \geq 25)$ & $1 /$ & \\
\hline \multirow[t]{2}{*}{ Obese $(35>\mathrm{BMI} \geq 30)$} & 15 & $0 \% .1$ \\
\hline & 60 & 25.6 \\
\hline Mean \pm SD & \multicolumn{2}{|c|}{$28.8 \pm 5.2$} \\
\hline \multicolumn{3}{|l|}{ Parity } \\
\hline Nullipara & 84 & 35.9 \\
\hline Primipara & 80 & 34.2 \\
\hline 2 & 58 & 24.8 \\
\hline 3 & 12 & 5.1 \\
\hline
\end{tabular}

Table (2): Distribution of the Studied Women According to their Previous Medical History $(\mathrm{n}=234)$

\begin{tabular}{|l|c|c|}
\hline \multicolumn{1}{|c|}{ Previous medical history } & $\begin{array}{c}\text { No. } \\
(\mathbf{n = 2 3 4})\end{array}$ & \% \\
\hline None & $\mathbf{2 1 0}$ & 90.9 \\
Chronic Hypertension & $\mathbf{1 0}$ & 2.8 \\
Cardiac Disease & $\mathbf{8}$ & 3.8 \\
Diabetes Mellitus & $\mathbf{6}$ & 2.5 \\
\hline
\end{tabular}


Table (3): Distribution of the Studied Women According to the Causes of Failed

Labor Induction (Indications for the Cesarean Section)

\begin{tabular}{|l|c|c|}
\hline \multicolumn{1}{|c|}{ Indications for the cesarean section } & $\begin{array}{c}\text { No. } \\
(\mathbf{n = 9 9 )}\end{array}$ & \% \\
\hline$\bullet$ Fetal distress & 49 & 49.5 \\
$\bullet$ Non engagement of fetal head & 17 & 17.1 \\
$\bullet$ Failure of labor progress & 12 & 12.1 \\
Using prostaglandin only for labor induction & 10 & 10.1 \\
Hyper-stimulation syndrome & 6 & 6.1 \\
$\bullet$ Labor dystocia & 5 & 5.1 \\
\hline
\end{tabular}

Table (4): Indications for Labor Induction among Women in the Successful and Failure Induction Groups $(\mathrm{n}=234)$

\begin{tabular}{|c|c|c|c|c|c|}
\hline \multirow{3}{*}{ Indication for Labor induction } & \multicolumn{4}{|c|}{ Outcome of induction } & \multirow{3}{*}{$M C P$} \\
\hline & \multicolumn{2}{|c|}{$\begin{array}{c}\text { Successful } \\
\text { induction } \\
(\mathrm{NVD}) \\
(\mathrm{n}=135)\end{array}$} & \multicolumn{2}{|c|}{$\begin{array}{c}\text { Failed } \\
\text { induction } \\
(\mathrm{CS})(\mathrm{n}=99)\end{array}$} & \\
\hline & No & $\%$ & No & $\%$ & \\
\hline Post term pregnancy $(\geq 42$ weeks $)$ & 28 & 20.7 & 23 & 23.2 & \\
\hline PROM & 61 & 45.3 & 49 & 49.5 & \\
\hline Pregnancy induce hypertension & 8 & 5.9 & 9 & 9.1 & \\
\hline PIH \& PROM & 6 & 4.4 & 6 & 6.1 & \\
\hline PROM \& Postdated & 26 & 19.3 & 9 & 9.1 & \\
\hline IUFD & 6 & 4.4 & 3 & 3.0 & \\
\hline
\end{tabular}


Table (5): Basic characteristics among Women in the Successful and Failure Induction Groups $(\mathrm{n}=234)$

\begin{tabular}{|c|c|c|c|c|c|}
\hline \multirow{3}{*}{ Characteristics } & \multicolumn{4}{|c|}{ Outcome of induction } & \multirow{3}{*}{$X^{2}(\mathbf{P})$} \\
\hline & \multicolumn{2}{|c|}{$\begin{array}{c}\text { Successful } \\
\text { induction (NVD) } \\
(\mathbf{n = 1 3 5 )}\end{array}$} & \multicolumn{2}{|c|}{$\begin{array}{c}\text { Failed } \\
\text { induction }(\mathrm{CS}) \\
(\mathrm{n}=99)\end{array}$} & \\
\hline & No & $\%$ & No & $\%$ & \\
\hline \multicolumn{6}{|l|}{ Age (years) } \\
\hline - $17-24$ & 14 & 10.4 & 44 & 44.4 & \multirow{3}{*}{$8.0(0.018)^{*}$} \\
\hline - $25-29$ & 64 & 47.4 & 33 & 33.3 & \\
\hline - $\quad 30-35$ & 57 & 42.2 & 22 & 22.2 & \\
\hline \multicolumn{6}{|l|}{ Parity } \\
\hline - Nullipara & 40 & 29.6 & 40 & 40.4 & \multirow{4}{*}{$\begin{array}{c}14.2 \\
(0.003)^{*}\end{array}$} \\
\hline - Primipara & 57 & 42.2 & 27 & 27.3 & \\
\hline - 2 & 36 & 26.7 & 22 & 22.2 & \\
\hline - 3 & 2 & 1.5 & 10 & 10.1 & \\
\hline \multicolumn{6}{|l|}{ History mode of Delivery } \\
\hline - $\quad \mathrm{C}-\mathrm{S}$ & 40 & 29.6 & 40 & 40.4 & \multirow{3}{*}{$3.1(0.206)$} \\
\hline - NVD & 86 & 63.7 & 52 & 52.5 & \\
\hline - Assisted & 9 & 6.7 & 7 & 7.1 & \\
\hline \multicolumn{6}{|l|}{ BMI } \\
\hline - Normal & 12 & 8.9 & 5 & 5.1 & \multirow{3}{*}{$1.3(0.510)$} \\
\hline - Overweight & 90 & 66.7 & 67 & 67.7 & \\
\hline - Obese & 33 & 24.4 & 27 & 27.3 & \\
\hline
\end{tabular}


Table (6): Methods of Labor Induction among Women in the Successful and Failure Induction Groups $(\mathrm{n}=234)$

\begin{tabular}{|c|c|c|c|c|c|}
\hline \multirow{3}{*}{ Methods of induction } & \multicolumn{4}{|c|}{ Outcome of induction } & \multirow{3}{*}{$M C P$} \\
\hline & \multicolumn{2}{|c|}{$\begin{array}{c}\text { Successful } \\
\text { induction (NVD) } \\
(\mathbf{n}=\mathbf{1 3 5})\end{array}$} & \multicolumn{2}{|c|}{$\begin{array}{c}\text { Failed } \\
\text { induction }(\mathrm{CS}) \\
(\mathrm{n}=99)\end{array}$} & \\
\hline & No & $\%$ & No & $\%$ & \\
\hline PGE 1(Misoprostol) & 41 & 30.4 & 48 & 48.5 & \\
\hline PGE 2 (dinoprostone) & 3 & 2.2 & 2 & 2.0 & \\
\hline PGE 1 + ARM + Sytoctinon & 57 & 42.3 & 5 & 5.1 & \\
\hline ARM + Sytoctinon & 13 & 9.6 & 15 & 15.2 & \\
\hline Sytoctinon & 3 & 2.2 & 19 & 19. 2 & 0.295 \\
\hline $\begin{array}{l}\text { Sweeping of membranes }+ \\
\text { ARM + Sytoctinon }\end{array}$ & 6 & 4.4 & 5 & 5.1 & \\
\hline PEG+Syntocinon & 12 & 8.9 & 5 & 5.1 & \\
\hline
\end{tabular}


Table (7): Neonatal outcomes among women in successful and failed induction Group $(\mathrm{n}=234)$

\begin{tabular}{|c|c|c|c|c|c|}
\hline \multirow[t]{2}{*}{ Neonatal outcomes } & \multicolumn{2}{|c|}{$\begin{array}{c}\text { Succesful } \\
\text { Induction } \\
\text { (NVD) } \\
\mathbf{n}=\mathbf{1 3 5}\end{array}$} & \multicolumn{2}{|c|}{$\begin{array}{c}\text { Faild } \\
\text { Induction } \\
(\mathrm{CS}) \mathrm{n}=99\end{array}$} & \multirow[t]{2}{*}{ FEP } \\
\hline & No & $\%$ & No & $\%$ & \\
\hline \multicolumn{6}{|l|}{ Neonatal complication } \\
\hline No complication & 116 & 85.9 & 45 & 45.5 & $0.028 *$ \\
\hline Asphyxia & 9 & 6.7 & 20 & 20.2 & 0.152 \\
\hline Need for resuscitation & 5 & 3.7 & 17 & 17.1 & 0.118 \\
\hline Birth Injury & 4 & 3 & 10 & 10.1 & 0.384 \\
\hline Admission to NICU & 1 & 0.7 & 7 & 7.1 & 0.245 \\
\hline \multicolumn{6}{|l|}{ APGAR SCORE AFTER 1 MINUTE } \\
\hline$<7$ & 20 & 14.8 & 35 & 35.4 & \multirow{2}{*}{$0.047 *$} \\
\hline$\geq 7$ & 115 & 85.2 & 64 & 64.6 & \\
\hline \multicolumn{6}{|l|}{$\begin{array}{l}\text { APGAR SCORE AFTER } 5 \\
\text { MINUTE }\end{array}$} \\
\hline$<7$ & 25 & 18.5 & 13 & 13.1 & \multirow[t]{2}{*}{0.845} \\
\hline$\geq 7$ & 110 & 81.5 & 86 & 86.9 & \\
\hline \multicolumn{6}{|l|}{ Birth weight } \\
\hline$<3500$ & 130 & 96.3 & 30 & 30.3 & \multirow[t]{2}{*}{$0.001 *$} \\
\hline$\geq 3500$ & 5 & 3.7 & 69 & 69.7 & \\
\hline
\end{tabular}

Table (7): Nurses' Attitudes towards Complementary/ Alternative Therapies ( $\mathrm{n}=90)$

\begin{tabular}{|l|c|c|}
\hline \multicolumn{1}{|c|}{ +ve attitude towards: } & Frequency & Percent \\
\hline Applications & 56 & 62.2 \\
Nurse role & 68 & 75.6 \\
Effectiveness & 46 & 51.1 \\
\hline Total attitude: & & \\
Agree (+ve) & 61 & 67.8 \\
Disagree (-ve) & 29 & 32.2 \\
\hline
\end{tabular}




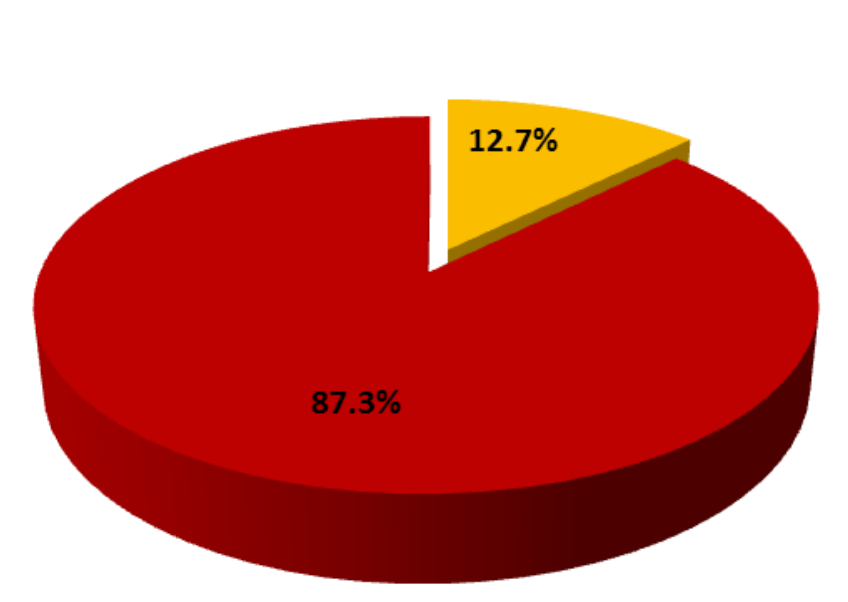

Induction

- No induction

PART (I): Incidence of labor induction and baseline characteristics of the studied women

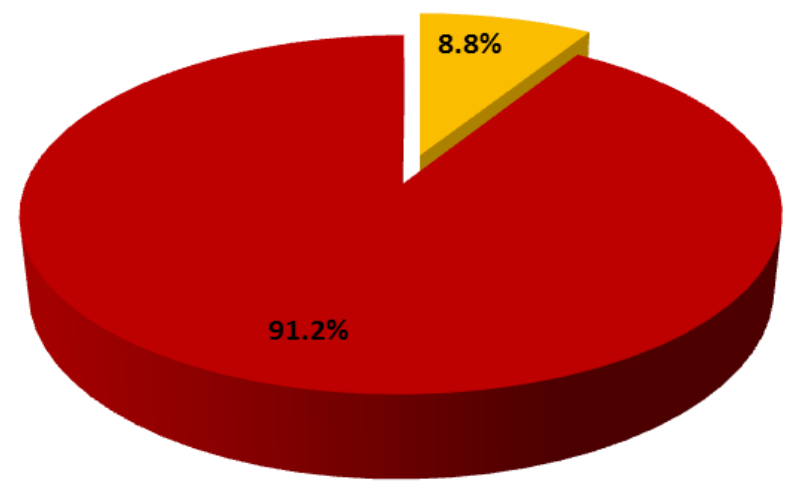

Induction

- No induction

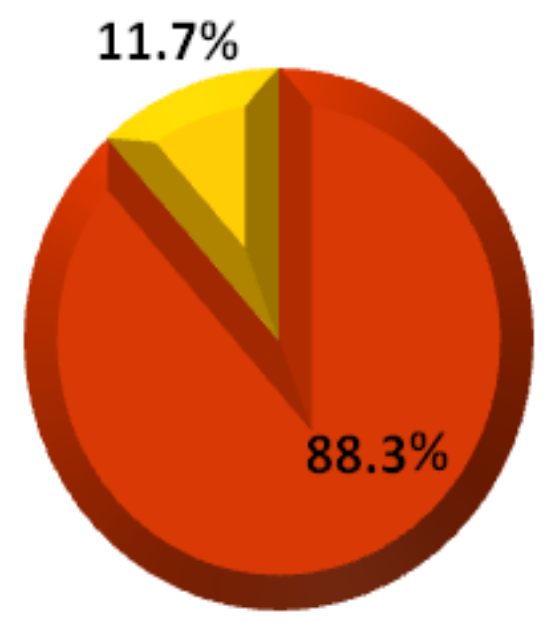

No $\mathbf{n y e s}$

Incidence at Mansoura University Hospital 


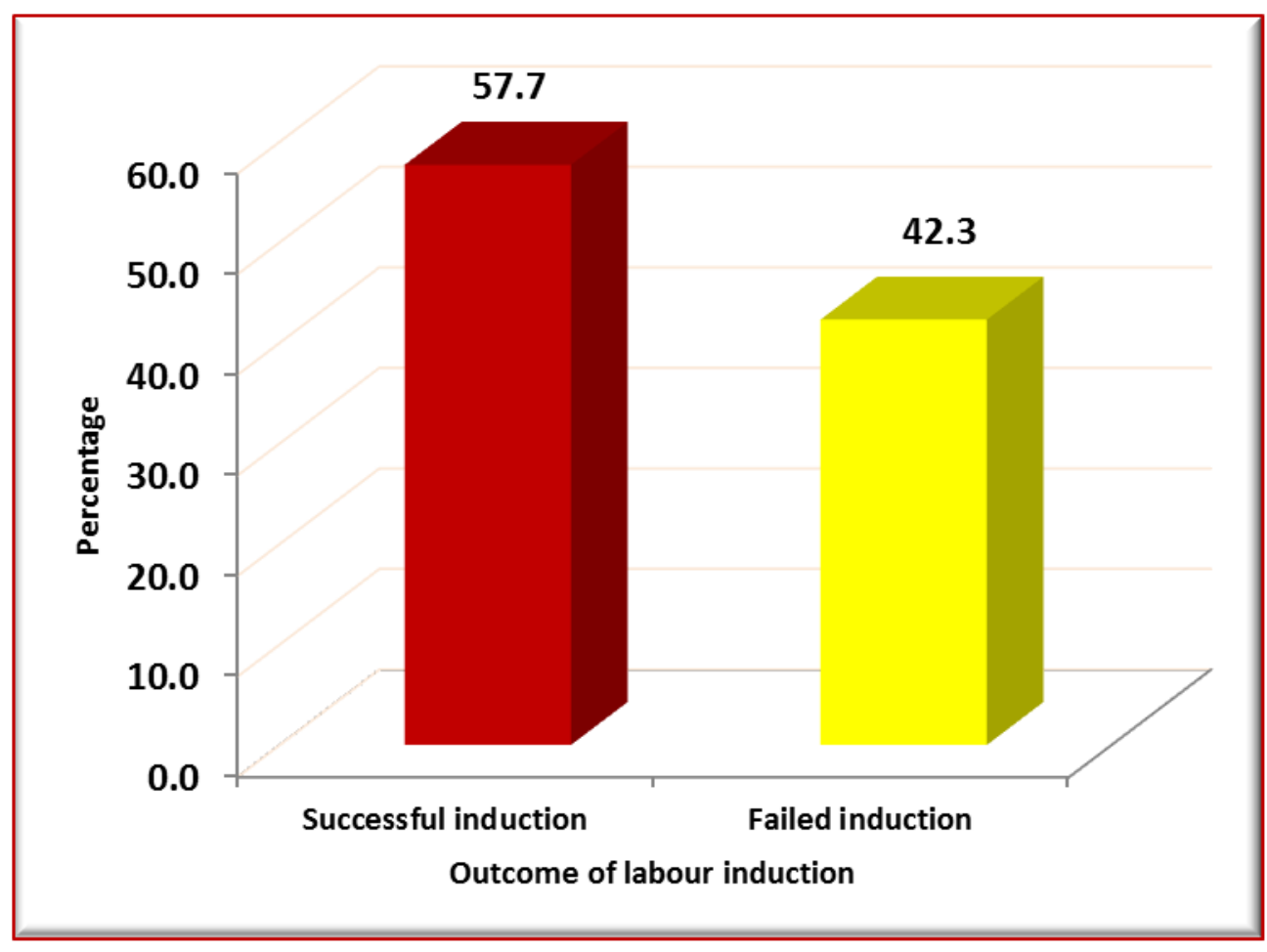

Part (I): Distribution of Studied Women According to the Outcome of Labor Induction $(\mathrm{n}=234)$

\section{DISCUSSION:}

Induction of labor (IOL) is a commonly performed obstetric procedure. It is indicated in cases where waiting for spontaneous onset of labor can jeopardize the maternal or fetal health. Rate of caesarean section is steadily increasing despite the risk associated with caesarean delivery. Most of the studies have found that there is a 2 fold increased risk for caesarean delivery with induction of labor compared to spontaneous labor (Bukola et al., 2012) .

Rate of Induction of labor has doubled in the past decade from 10 to $20 \%$ (Rayburn $\&$ Zhang, 2002). In some institutions, the rate of IOL is as high as $40 \%$. Some of the increase in this rate is related to a rise in the number of medically and obstetrically indicated inductions, however, it appears that marginally indicated and elective inductions account for a large proportion of IOL. One of the other contributing factors for increasing rate of IOL is the concern of the patients and healthcare providers about 
the possible risk of fetal demise at term or post term with the expectant management (Moore \& Rayburn 2006).

Borderline reduced Amniotic Fluid Index (AFI), reduced fetal movements, mild pregnancy induced hypertension $(\mathrm{PIH})$, favorable Bishop score, small for gestational age fetus, excess liquor, macrosomia, Impaired Glucose Tolerance at or after 36 weeks of pregnancy are some of the common marginal indications. Major concerns associated with induction of labor are the potential for increased risk of caesarean delivery, iatrogenic prematurity and cost. Emergency CS as compared to simple vaginal delivery is in turn associated with a higher rate of excessive blood loss, post partum infection and maternal mortality.

Known risk factors for failed IOL are cervical status, parity, advanced maternal age, nulliparity, diabetes and hypertension. Duration of induction is also a risk factor for caesarean delivery in IOL. Nevertheless, IOL may result in undesirable effects such as; increased CS rates, PPH and fetal distress (Vardo et al., 2011).

An ideal method of induction must be cost effective, ensure efficacy and safety for the mother and the fetus with minimal induction delivery interval and should be convenient for the patient and the medical staff. All methods were effective in IOL in terms of delivery interval and mode of delivery but the combined method, that is, medical and surgical had the best results (Kaur et al., 2013). Therefore, the present study was carried out to identify the outcomes of labor among women underwent IOL. It was a prospective observational study on women undergoing induction of labor, recruited from the labor ward at the Maternity Department of Mansoura University Hospital and El-dekernis Hospital.

The present study finding shows that the incidence of labor induction in the studied sample was $11.7 \%$. This proportion is lower than that reported by Mealing et al., (2009) in Australia 29.13\%, Humphrey \& Tucker, (2009) in England 32.3\% and Laughon et al., (2012) in USA 40.0\%. However, Abdel-Aleem, (2011) study in Assiut- Egypt, found that the incidence of IOL was 9.3\% of all deliveries.

The discrepancy between the current study finding and the other studies is related to the rate of induction of labor and elective cesarean sections, with fewer inductions in 
areas with a more liberal use of elective cesarean indications. Moreover, in Egypt there are limited facilities for sophisticated fetal monitoring in labor and IOL is only done for obstetrical or medical indications and excluding elective IOL.

The present study finding indicates that more than two fifth $42.3 \%$ of women were exposed to failed induction (CS). This rate is much higher than that reported by Vrouenraets et al., (2005) Dutch study 23.4\%, (Caliskan et al., 2004) Turkish study 12.0\% and Al-Shaikh et al., (2012) in the Kingdom of Saudi Arabia 16.0\%. Thus although induction of labor has merit as a therapeutic option when the benefits of expeditious delivery out- weigh the risks of continuing the pregnancy, the benefits of labor induction must be weighed against the potential maternal and fetal risks associated with this procedure (Rock Vill et al., 2009)

The present study finding revealed that the failure rate in induction of labor was more common in nulliparous women. In the same line Khan et al., (2012) study in Pakistan found that, failed induction was 4.6 times more likely in nulliparous patients compared to their multiparous counter part. Bodner-Adler et al., (2005) also cite primiparity as significantly reducing the probability of successful induction compared to their multiparous counter part. In addition, in nulliparas more than 41 weeks with an unengaged vertex, the risk of cesarean delivery increases 12-fold compared with that of those with an engaged vertex (Shin and Associates, 2004). There is no increased risk if the engaged fetal head is occiput posterior at the time of induction (Peregrine $\&$ colleagues, 2007).

The current study finding reported that women age less than 25 years were significantly more liable for failed induction (CS) than a successful one. This finding is contradicting with Walker et al., (2012) who reported that, women over 35 years were at higher risk for failed induction. They explained this by the fact that the advanced maternal age put the women at great risk of hypertensive disorders, gestational diabetes, placenta previa and placental abruption and even the women themselves typically believe that their age puts their infant at increased risk.

The present study also revealed that, obese and morbidly obese women were more likely to have failed induction. Similarly, Arrowsmith et al., (2011) study in United Kingdom 
highlighted that IOL for obese women is associated with increased rates of CS. A possible explanation for failed induction of labor with obesity was the increasing risk of gestational diabetes, gestational hypertension, macrosomia, shoulder dystocia and poor myometrial contractility.

Timely onset of labor and delivery is an important determinant of maternal and perinatal outcome. Both preterm and post term births are associated with higher rates of perinatal morbidity and mortality than pregnancies delivered at term. Gestation age has been reported to be associated with the success or failure of IOL. In Khan et al., (2012) study "about Factors associated with failed induction of labor in a secondary care hospital" CS were 1.5 times more likely to have gestational age of more than 40 weeks than women having vaginal delivery.

Moreover, a meta analysis of 19 randomized trial showed routine labor induction at $>$ 41 weeks of gestation to be associated with significantly lower rate of perinatal mortality than expectant management and no significant increase in the caesarean birth rate with induction at 41 week (Gulmezoglu, 2006). The present results are contrary to the existing literature, which demonstrate that the gestational age of 37 to less than 42 weeks had statistically raised rates of successful induction $(p=0.001)$ when compared to women with gestational age more than 40 weeks. This may be explained by the practice of inducing labor just after 40 weeks rather than following expectant management till 41 weeks when majority of women may present in spontaneous labor. Another explanation of this result may be due to the fact that lower gestational age may favorably impact the mode of delivery in two important ways; first, because fetal weight increases continuously during the term period. Second, because placental function decreases continuously during the term period.

Various methods have been recommended for induction of labor such as intracervical Foleys balloon, prostaglandin E2 and I/V Oxytocin etc...Rayamajh et al., (2009); Kaur et al., (2013) found that the combination of induction methods leads to vaginal delivery and decrease the incidence of CS. Meanwhile, Harandi et al., (2012) study in Iran added that uterine hyper-stimulation or tachysystole, fetal tachycardia and gastrointestinal symptoms were more pronounced in women who only received misoprostol than the women who received combined methods for IOL. The above mentioned findings matched well with 
the present study finding, where medical and surgical methods (PGE1, ARM and syntocinon) when used in combination gave the best results in terms of both inductiondelivery interval and successful vaginal delivery as compared to when either of these methods was used individually.

The condition of the cervix at the start of induction is an important predictor, with the modified Bishop score being a widely used scoring system. Induction of labor results in high failure rate if the cervix is not ripe (Caliskan et al., 2004; Park, 2009). The most important element of the Bishop score is dilatation (Chandra, 2001), although other elements like consistency, effacement, station and position are also important in predicting successful induction in both nulliparous and multiparous women.

\section{CONCLUSION:}

According to the findings of the present study, it can be concluded that:

- Almost three fifth of women had successful induction of labor, while more than one fifth underwent cesarean section as a result of failed labor induction.

- The common indications for induction of labor were; PROM, post term pregnancy, premature rupture of membrane plus post term pregnancy and pregnancy induced hypertension.

- Medical and surgical methods (PGE1, ARM and syntocinon) when used in combination gave the best results in terms of both induction-delivery interval and successful vaginal delivery as compared to when either of these methods was used individually.

- Successful induction was more likely with gestational age between 37 weeks to 42 weeks. While, other variables which increased the likelihood of failed induction were maternal age less than 25 years old and elevated BMI.

- Women who had a shorter IDI period resulted in successful induction outcome. Meanwhile, women who took more than 24 hours were mostly exposed to CS. Bishop score was higher in the successful group than in the failed induction groups.

- It is evident that low Apgar score after 1 minute is more common in women with failure in labor induction than those who had successful induction. 


\section{RECOMMENDATIONS:}

On the basis of the most important findings of the study, the following recommendations are suggested:

- It is important to monitor the woman and her fetus closely undergoing labor induction once labor is established by labor induction.

- The indications for induction must be documented, and discussion should include reason for induction, method of induction and risks, including failure to achieve labor and possible increase risk of cesarean section.

- Health care providers should assess the cervix (using the Bishop score) to determine the likelihood of success and to select the appropriate method of induction.

- Written clinical guidelines or nursing protocol for management of the women undergoing labor induction should be present in the labor and delivery unit.

- Further researches should be conducted to study the same problems using large sample of the women.

\section{REFERENCES:}

Abdel-Aleem H. (2011): Misoprostol for cervical ripening and induction of labor: RHL commentary. The WHO Reproductive Health Library; Geneva: World Health Organization. Available at: http://apps.who.int/rhl/pregnancy_childbirth/induction/ CD000941_abdel-aleemh_com/en/. Last accessed was at 21/4/2014.

ACOG (2003): Practice Bulletin Number49, December Dystocia and augmentation of labor obstet Gynecal; 102:1445.

Adair CD. (2000): Non-pharmacologic approaches to cervical priming and labor induction. clin obstet Gynecol ; 43:447-454 .

Ade-Ojo IP., Kuti O., Loto OM. and Ogunniyi SO. (2011): A prospective comparison of the 30- minute and 60- minute oxytocin dose incremental schedules for induction of labor at term. Nepal Journal of Obstetrics \& Gynecology; 6(1): 35-40. 
Agency for Healthcare Research and Quality's (2009): Maternal and neonatal outcomes of elective induction of Labor: A Systematic review and cost-effectiveness analysis. Available at: www.effectivehealthcare.ahrq.gov. Last accessed was at: 8/3/2014.

Alfirevic Z., Kelly A. and Dowswell T. (2009): Intravenous oxytocin alone for cervical ripening and induction of labor. Cochrane Database Syst Rev; 7(4):CD003246. doi: 10.1002/14651858. CD003246.pub2.

Alfonsi and Sharyn (2006): Labor induction drug under fine CBS Evening News.

Allen VM., O'Connell EM. and Baskett TF. (2006): Maternal association of indication of induction labor at term obstet Gynecol 108 ( 2 ) :286-94

Alliance U., Keith R. and Sullivan. (2001): Pharmaceuticals Syntocinon. Summary of product characteristics.

Al-Shaikh GK., Wahabi HA., Fayed AA., Esmaeil SA. and Al-Malki GA. (2012): Factors associated with successful induction of labor. Saudi Med J; 33(3): 298-303.

Arrowsmith S., Wray S. and Quenby S. (2011): Maternal obesity and labor complications following induction of labor in prolonged pregnancy. BJOG 2011; $118: 578-588$

Bodner-Adler B., Bodner K. and Patelsky N. (2005): Influence of labor induction on obstetric outcomes in patients with prolonged pregnancy: a comparison between elective labor induction and spontaneous onset of labor beyond term. J Obstet \& Gynecol; 117(7-8):287-294

Bukola F., Nafiou ID., M'Mimunya M., Wolomby M. and Mugerwa A. (2012): Unmet need for induction of labor in Africa: secondary analysis from the 2004 - 2005 WHO Global Maternal and Perinatal Health Survey A cross-sectional survey. Open access journal; 12(722): 1-7.

Dutta DC. (2010): Induction of labor, Textbook of obstetrics. $7^{\text {th }}$ ed, New central Book Agency (P) Ltd, London: 46. 
Gulmezoglu AM., Crowther CA., and Middletaion P. (2006): Induction of labor for improving birth outcomes for women at or beyond term. Cochrane Database Syst Rev; CD004945

Humphrey T. and Tucker J. (2009): Rising rates of obstetric Intervention: exploring the determinants of induction of labor. Journal of Public Health; 31(1): 88-94.

Joane Crane et al. (2001): society of obstetricians and gynecologists of Canada. SOGC clinical practice guide line No. 107, August 2001

Kaur P., Kaur M., Kaur K., Manjit MK. and Goel P. (2013): A Study of Outcome of Induction of Labor: Medical Versus Surgical. Indian Journal of Clinical Practice; 24(7): $651-654$

Khan N., Ahmed I., Malik A. and Sheikh L. (2012): Factors associated with failed induction of labor in a secondary care hospital. J Pak Med Assoc; 62(1): 6-10.

Mealing NM., Roberts CL., Ford JB., Simpson JM. and Morris JM. (2009): Trends in induction of labor, 1998-2007: a population based study. Aust N Z J Obstet \& Gynaecol; 49(6):599-605.

Moore, LE. and Rayburn WF. (2006): Elective induction of labor. Clin Obstet Gynecol; 49: 698-704.

Norwitz E., Robison J. and Repke J. (2002): Labor and delivery in gAbbe SG, Niebyl JR, simfon JL, eds- obstet: Normal and problem pregnancies $4^{\text {th }}$ ed., New York, Churchill Livingstone; 353-94

Rayburn, WF, and Zhang, J. (2002): Rising rates of labor induction: present concerns and future strategies. Obstet Gynecol; 100:164-7.

Simpson KR. and Creehan PA. (2014): Labor and birth. AWHONN'S Perinatal Nursing. $4^{\text {th }}$ ed., USA; 342. 
Vardo JH., Thornburg LL. and Glantz JC. (2011): Maternal and neonatal morbidity among nulliparous women undergoing elective induction of labor. J Reprod Med; 56(1): 25-30.

Vrouenraets FP., Roumen FJ., Dehing CJ., van den Akker ES., Arts MJ. and Scheve EJ. (2005): Bishop score and risk of cesarean delivery after induction of labor in nulliparous women. Obstet Gynecol 2005; 105: 690-7.

Walker K., Bugg G., Macpherson M., McCormick C. and Wildsmith C. (2012): Induction of labor versus expectant management for nulliparous women over 35 years of age: a multi-centre prospective, randomized controlled trial. Pregnancy and Childbirth J; 12(145): 1-7. 


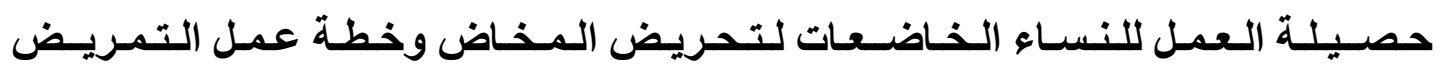

$$
\begin{aligned}
& \text { أ.د. ســـــاء علـي نـور، د. نـجــاة صــلاح شـلـب، زينب فتحي محمد أبو الوفا. }
\end{aligned}
$$

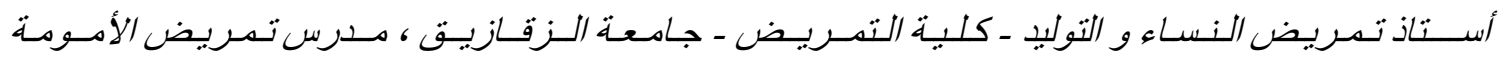

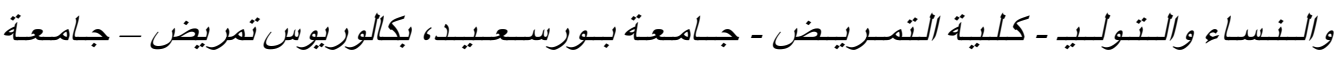

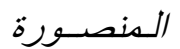

\section{الخلاصة}

الو لادة المحفزه هي بدء تقلصات الرحم باستخدام الطرق الدو ائيه و الجر احيه التي تؤدي إلي إنهاء الحمل قبل بداية الولادة التلقائية بعد اكتمال نمو الجنين ـ الولادة المحفزه هي التنخل الأكثر شيو عا أثناء فتره الحمل في الدول المتقدمة والدول النامية. وتهدف هذه الدراسة الي التعرف علي نتائج الولادة للسيدات الخاضعات لتحفيز الو لادة. عينه هذه الدر اسة تتألف من ع ب س سيده حضرنا إلي مكان الدراسة وقد خضعنا

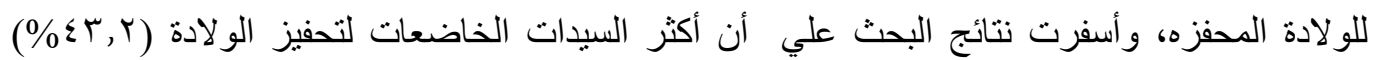

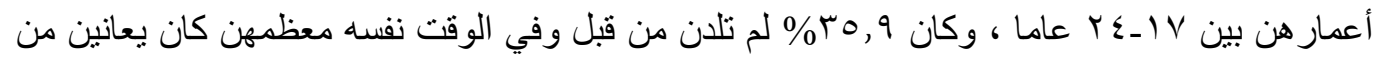
السمنة المفرطة وزيادة الوزن. وكانت الغالبية العظمي من النساء (9, •9\%) ليس لايهن اي مشاكل

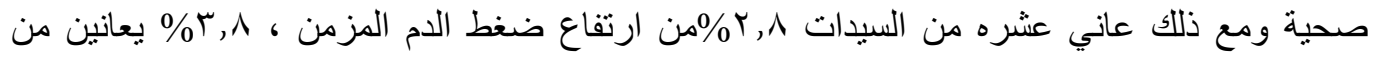
أمر اض القلب ، ب, 0 \% لديهن تاريخ داء السكري. وتوصي الدراسة بأنه يجب أن يوثق سبب الولادة

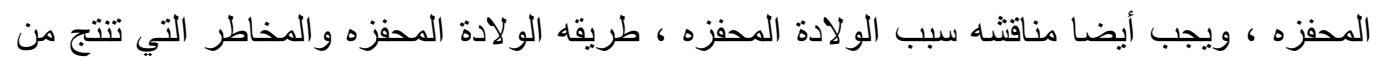
الو لادة المحفزه منل الفشل في تحقيق الو لادة واحتمال خطر الولادة القيصرية ويجب علي مقدمي الرعاية الصحية تقييم عنق الرحم باستخدام (قياس بيشوب) لتحديد احتمالات النجاح واختبار الطريقة المناسبة 